\title{
Aspen development on similar soils in Minnesota and British Columbia after compaction and forest floor removal
}

\author{
by Douglas M. Stone ${ }^{1,2}$ and Richard Kabzems ${ }^{3}$
}

\begin{abstract}
Forest management practices that decrease soil porosity and remove organic matter can reduce site productivity. We evaluated effects of four treatments-merchantable bole harvest (MBH) with three levels of soil compaction (none, light, or heavy), and total woody vegetation harvest plus forest floor removal (FFR) — on fifth-year regeneration and growth of aspen (Populus tremuloides Michx.) growing on soils with similar textures (20-40 cm silt loam over clay loam till) in northern Minnesota (MN) and northeastern British Columbia (BC). Overall mean sucker density was significantly greater in $\mathrm{BC}$ than in $\mathrm{MN}$, and mean height was significantly lower. Soil compaction did not affect sucker density in BC, but significantly reduced it in $\mathrm{MN}$, primarily due to late spring treatment. In BC, mean sucker heights generally decreased with level of compaction, but only the differences between non-compacted and the heavy compaction treatments were significant. On the MN plots, sucker heights were reduced significantly by compaction. Treatment responses were similar on both sites: (1) the greatest sucker densities were in the FFR treatment; (2) greatest mean heights were on the non-compacted $\mathrm{MBH}$ plots and were significantly greater than those in the FFR treatment; (3) sucker heights generally decreased with level of compaction; and (4) soil compaction decreased the number of suckers that had reached a dbh of $25 \mathrm{~mm}$ after five years and will likely delay future stand development and reduce site productivity.
\end{abstract}

Key words: sustainable management, organic matter removal, soil compaction, aspen sucker density, height growth

Les pratiques d'aménagement forestier qui réduisent la porosité du sol et qui enlèvent la matière organique peuvent réduire la productivité d'une station. Nous avons évalué les effets de quatre procédures de récolte de la tige marchande (MBH) selon trois niveaux de compaction du sol (aucun, léger, important) et la récolte de toute la végétation ligneuse ainsi que l'enlèvement du substrat forestier (FFR) sur la régénération de cinq ans et la croissance du tremble (Populus tremuloides Michx.) en croissance sur des sols de texture semblable (20 à $40 \mathrm{~cm}$ de silt loameux sur un till d'argile et de loam) dans le nord du Minnesota (MN) et le nord-est de la Colombie-Britannique (C.-B.) La densité totale moyenne des drageons était significativement plus élevée en C.-B. qu'au MN, et la hauteur moyenne était significativement inférieure. La compaction du sol n'a pas affecté la densité des drageons en C.-B., mais elle a été significativement réduite au MN, principalement à cause des opérations effectuées tard au printemps. En C.-B., la hauteur moyenne des drageons diminuait généralement selon le niveau de compaction, mais seul les différences entre les opérations sans compaction et avec beaucoup de compactions étaient significatives. Dans les parcelles du MN, les hauteurs moyennes ont été réduites significativement par la compaction. Les réactions aux opérations étaient similaires sur les deux sites : (1) les plus importantes densités de drageons se retrouvaient dans les traitements FFR; (2) les plus importantes hauteurs moyennes se retrouvaient dans les parcelles non compactées MBH et étaient significativement plus grandes que celles des traitements FFR; (3) les hauteurs des drageons diminuaient généralement en fonction du niveau de compaction; et (4) la compaction du sol réduisait le nombre de drageons qui avaient atteint un dhp de $25 \mathrm{~mm}$ après cinq ans et retardera probablement le développement futur du peuplement et réduira la productivité de la station.

Mots-clés : aménagement durable, enlèvement de la matière organique, compaction du sol, densité des drageons de tremble, croissance en hauteur

\section{Introduction}

Maintaining soil productivity is critical for sustainable forest management. Forest management activities that decrease soil porosity and remove organic matter have been associated with declines in site productivity (Greacen and Sands 1980, Agren 1986, Standish et al. 1988, Grier et al. 1989). As part of an international network of cooperative studies on long-term soil productivity (LTSP) (Powers et al. 1990, Tiarks et al. 1993), we are evaluating effects of three levels of organic matter removal (OMR) and three levels of soil compaction in the aspen (Populus tremuloides Michx. and $P$. grandidentata Michx.) forest type on four sites in the northern Great Lakes region and one site in northeastern British Columbia (Kabzems 1996, Stone and Elioff 1998, Stone et al. 1999, Stone 2001). The research is designed to determine how changes in soil porosity and organic matter content affect soil processes controlling forest pro-

${ }^{1}$ USDA Forest Service, North Central Research Station, 1831 Highway 169 East, Grand Rapids, MN 55744, USA. E-mail: dstone01@ fs.fed.us

${ }^{2}$ Author to whom correspondence should be sent.

${ }^{3}$ British Columbia Ministry of Forests, Prince George Region, $880872^{\text {nd }}$ Street, Fort St. John, BC V1J 6M2.

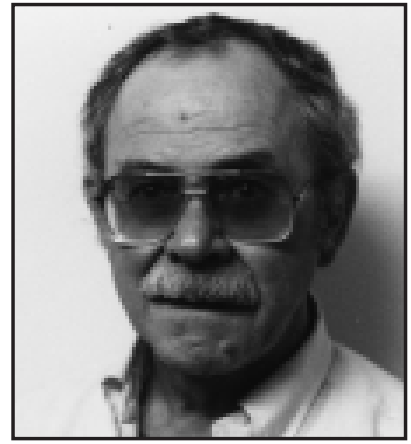

Douglas M. Stone

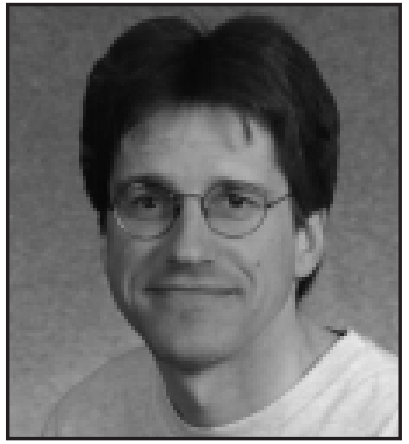

Richard Kabzems ductivity and sustainability and to compare responses among major forest types and soil groups across the United States and Canada.

The objectives of these aspen studies are to monitor changes in soil properties following forest harvesting and application of nine combinations of OMR and soil compaction treatments, and secondly, to measure responses of the aspen regeneration and associated vegetation. Fifth-year results from four 
treatments in a pilot study in north-central Minnesota (MN) and fourth-year results of four treatments in northeastern British Columbia (BC) were reported earlier (Stone and Elioff 1998, Kabzems 2000a). Fifth year results from four treatments-merchantable bole harvest $(\mathrm{MBH})$ with three levels of soil compaction (none [C0], light [C1], or heavy [C2]), and total vegetation harvest plus forest floor removal (FFR) are now available. We report effects on fifth-year regeneration and growth of aspen growing on soils with similar textures (20-40 cm silt loam over clay loam till) on sites in $\mathrm{MN}$ and $\mathrm{BC}$ separated by approximately $2300 \mathrm{~km}$. Treatment effects on soil properties will be reported when fifth-year data are available for all nine treatment combinations.

\section{Methods}

\section{Stand and Site Conditions}

Minnesota - The study was installed in the spring of 1993, on the Chippewa National Forest in north-central Minnesota $\left(47^{\circ} 20^{\prime} \mathrm{N}, 94^{\circ} 30^{\prime} \mathrm{W}\right)$. The climate is continental with warm summers (mean July temperature $20^{\circ} \mathrm{C}$ ), cold winters (mean January temperature $-17^{\circ} \mathrm{C}$ ), and $640 \mathrm{~mm}$ of precipitation; about half occurs during the growing season. The site was occupied by a fully stocked, 70-year-old stand of predominantly trembling aspen; the primary associated species were red maple (Acer rubrum L.), basswood (Tilia americana L.), sugar maple(A. saccharum Marsh.), northern red oak (Quercus rubra L.), and eastern white pine (Pinus strobus L.). Basal area averaged $37 \mathrm{~m}^{2}$ $\mathrm{ha}^{-1}$. The predominant herbaceous species were twisted stalk (Streptopus roseus), bellwort (Uvularai sessilifolia), lady fern (Athyrium filix-femina), ostrich fern (Matteucic struthiopteris), sarsaparilla (Aralia nudicaulis), and bracken fern (Pteridium aquilinium). The site is on the Guthrie till plain; the surface soils developed from a silt loam loess cap 30 to $40 \mathrm{~cm}$ deep underlain by clay loam till. Site index (age 50) for aspen is about $23 \mathrm{~m}$. The pre-harvest forest floor thickness averaged $6.2 \mathrm{~cm}$ with a dry weight of $131 \mathrm{Mg} \mathrm{ha}^{-1}$.

British Columbia - The study was installed in the spring of 1995 , in the Dawson Creek Forest District ( $\left.55^{\circ} 58^{\prime} \mathrm{N}, 120^{\circ} 28^{\prime} \mathrm{W}\right)$. The climate is generally continental with moderately warm summers (mean July temperature $15^{\circ} \mathrm{C}$ ), cold winters (mean January temperature $-18^{\circ} \mathrm{C}$ ) and $500 \mathrm{~mm}$ of precipitation; approximately half of which falls during the growing season. The site is representative of mesic aspen ecosystems in the Boreal White and Black Spruce (BWBS) zone (Kabzems 1996). The site was occupied by a fully stocked, 100-year-old aspen stand with a basal area of $34 \mathrm{~m}^{2} \mathrm{ha}^{-1}$. The primary associated species were white spruce (Picea glauca (Moench) Voss), lodgepole pine (Pinus contorta Dougl.), and balsam poplar (P. balsamifera $\mathrm{L}$.). The soils are silt loam 20 to $30 \mathrm{~cm}$ thick over clay loam till. Site index (age 50) for aspen was $18 \mathrm{~m}$. The pre-harvest forest floor thickness averaged $7.0 \mathrm{~cm}$ with a dry weight of $149 \mathrm{Mg} \mathrm{ha}^{-1}$.

\section{Treatments}

Minnesota - The stands were harvested during January and February 1993. Snowfall during November and December 1992 was somewhat greater than normal and air temperatures were slightly greater than the 30-year mean. Thus, soil frost was thin and discontinuous initially, and ranged from 5 to $10 \mathrm{~cm}$ when logging was completed. Snow depth increased from about $30 \mathrm{~cm}$ initially to $46 \mathrm{~cm}$ during the logging operations. On the noncompacted (MBHC0) plots, the trees were felled with chainsaws and winched off the plots with a cable skidder located outside the plot boundaries. On all other plots, the stems were cut with a Case-Drott model 40 feller-buncher and placed outside the plot boundaries; skidders did not enter any of the plots. The FFR treatment consisted of manually removing all coarse woody material and windrowing the forest floor materials, using a power driven sidewalk sweeper with a revolving wire brush head $46 \mathrm{~cm}$ in diameter and $90 \mathrm{~cm}$ wide; the materials were piled outside a 5 to 10 -m-wide buffer zone surrounding the $50 \times 50 \mathrm{~m}$ treatment plots. The light compaction treatment (MBHC1) consisted of a double pass, at right angles, across the plots with a model D-7 Caterpillar tractor, advancing one track width $(61 \mathrm{~cm})$ each pass. The heavy compaction treatment (MBHC2) included the light treatment followed by a double pass, at right angles, with a Michigan model 75C front-end loader with $52 \times 63.5 \mathrm{~cm}(20.5 \times 25$ in. $)$ tires, advancing one tire width each pass. There were three replications for each of the four treatments.

The objective of the compaction treatments was to increase bulk density of the surface soil by either $15 \%$ or $30 \%$ without damaging the root systems by rutting. This was accomplished successfully in previous years on the Marcell Experimental Forest and the Ottawa and Huron-Manistee National Forests. However, spring and early summer rainfall were higher than normal in 1993 and delayed study installation on this site. The frequent rainfall and the desire to avoid rutting caused numerous delays in application of the treatments. Thus, the suckers had begun to emerge by the time the soil had drained sufficiently to complete the compaction treatments, and many were broken by the machine traffic.

British Columbia - The area was harvested in January and February 1995. Winter harvest on frozen ground ensured that no soil disturbance occurred during the harvesting phase (Kabzems 1996). Only the feller-buncher entered the plots during harvest. Cut stems were placed outside the plot boundaries and removed with a grapple skidder. The first group of nine $40 \times 70 \mathrm{~m}$ treatment plots was established in May 1995. The non-compacted (MBHC0) plots received no post-harvest compaction. The compaction treatments were applied with a vibrating pad mounted on an excavator. The light treatment (MBHC1) compressed the surface mineral soil 1 to $2 \mathrm{~cm}$, and the heavy treatment (MBHC2) compressed the surface soil 4 to $5 \mathrm{~cm}$. The FFR treatment consisted of removing all coarse woody material from the plots and then stripping the forest floor materials with an excavator. There were two replications for each of the three MBH-compaction level combinations. The FFR plots each received one (none, light, or heavy) of the compaction treatments. The effects of compaction on sucker density were not significant (Fig. 1) so we pooled these data and analyzed them as three replications of the main FFR treatment.

\section{Measurements and Analyses}

Measurement protocols varied somewhat between sites. On the MN site, all measurements were made within the interior $40 \times 40 \mathrm{~m}$ area of each $50 \times 50 \mathrm{~m}$ treatment plot. In September 1997, after five growing seasons, the basal diameter (15-cm height) of all woody species was measured and recorded by $2-\mathrm{mm}$ diameter classes on eight randomly located 


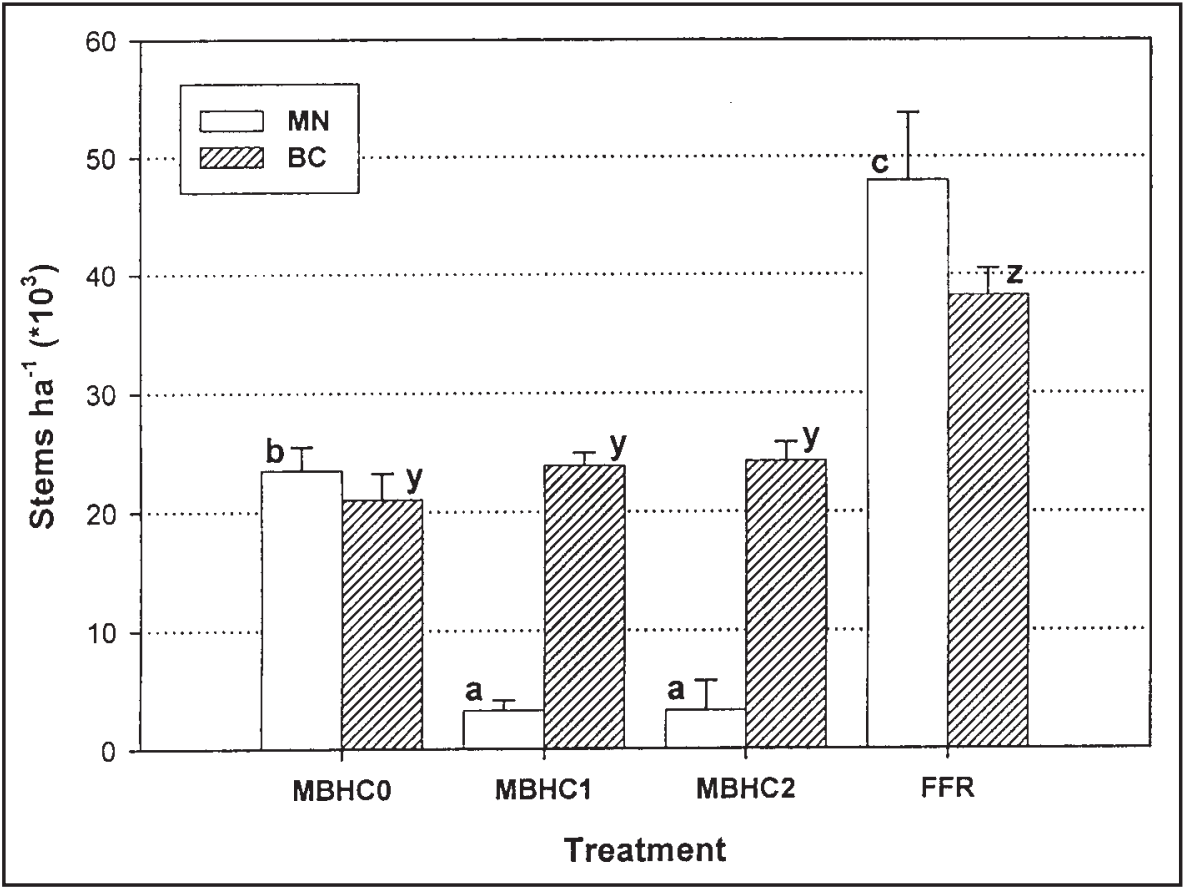

Fig. 1. Mean fifth-year aspen sucker density by treatment. Within sites, means followed by the same letter do not differ significantly at $p \leq 0.05$; error bars $=$ standard error of the means. $\mathrm{MBH}=$ merchantable bole harvest; $\mathrm{C} 0=$ no compaction; $\mathrm{C} 1=$ light compaction; $\mathrm{C} 2=$ heavy compaction; FFR = total vegetation harvest plus forest floor removal.

5.0- $\mathrm{m}^{2}$ subplots per plot. Mean height of aspen suckers in each diameter class was recorded to the nearest 5 -cm class. On the $\mathrm{BC}$ site, density and height of aspen suckers and associated species were measured on nine randomly selected $50-\mathrm{m}^{2}$ subplots per plot in September 1999. On each subplot, average height of the aspen suckers was visually estimated and height of the four tallest suckers was measured. In early June 2000, during the sixth growing season, the basal diameter $(15-\mathrm{cm}$ height $)$ of aspen was measured and classified as $<25-\mathrm{mm}$ or $>25-\mathrm{mm}$ diameter on three randomly selected $50-\mathrm{m}^{2}$ subplots per plot.

For each site, all subplot data were composited and the site and treatment effects were evaluated by two-way analysis of variance of the plot-level means. First, the data from both sites were combined and the overall effects were analyzed using a site-treatment-site*treatment model (Analytical Software 2000). The data for each site were then analyzed separately with a randomized complete block (treatment-replication-treatment*replication) model. Where main effects were significant at $p \leq 0.05$, comparisons among means were made with the Least Significant Difference procedure at the $95 \%$ confidence level.

\section{Results and Discussion Natural Variation}

Trembling aspen is the most widely distributed commercial forest species in North America (Little 1971). Only one other hardwood species, the closely related Eurasian aspen $(P$. tremula), has a wider range. Both species typically exhibit marked phenotypic variability throughout their transcontinental ranges (Harper et al. 1985). Because of the greater variation within species than between species, $P$. tremuloides and $P$. tremula have been considered as a single circumboreal superspecies for taxonomic purposes (Harper et al. 1985) and from the standpoint of self-thinning rates and stockability (Perala et al. 1995, 1999). Considering the geographic differences between sites (Table 1) and the broad genotypic and phenotypic variability between clones (Jones and DeByle 1985), we were not
Table 1. Stand and soil characteristics of aspen LTSP sites in northcentral Minnesota and northeastern British Columbia

\begin{tabular}{lcc}
\hline Parameter & Minnesota & British Columbia \\
\hline Installation date & Spring, 1993 & Spring, 1995 \\
Latitude & $47^{\circ} 20^{\prime} \mathrm{N}$ & $55^{\circ} 58^{\prime} \mathrm{N}$ \\
Longitude & $94^{\circ} 30^{\prime} \mathrm{W}$ & $120^{\circ} 28^{\prime} \mathrm{W}$ \\
Mean January temperature & $-17^{\circ} \mathrm{C}$ & $-18^{\circ} \mathrm{C}$ \\
Mean July temperature & $20^{\circ} \mathrm{C}$ & $15^{\circ} \mathrm{C}$ \\
Mean precipitation $(\mathrm{mm})$ & 640 & 500 \\
Stand age $($ years $)$ & 70 & 100 \\
Basal area $\left(\mathrm{m}^{2}\right.$ ha $\left.^{-1}\right)$ & 37 & 34 \\
Site index $(\mathrm{m})$ & 23 & 18 \\
Silt loam cap $(\mathrm{cm})$ & $30-40$ & $20-30$ \\
FF thickness $(\mathrm{cm})$ & 6.2 & 7 \\
FF dry weight $\left(\mathrm{Mg} \mathrm{ha}^{-1}\right)$ & 131 & 149
\end{tabular}

Table 2. Overall mean fifth-year density and height of aspen suckers in north-central Minnesota and northeastern British Columbia

\begin{tabular}{lcc}
\hline Site & $\begin{array}{c}\text { Density }^{\mathbf{a}} \\
\left(\mathbf{1 0}^{\mathbf{3}} \mathbf{h a}^{\mathbf{- 1}}\right)\end{array}$ & $\begin{array}{c}\text { Height } \\
(\mathbf{c m})\end{array}$ \\
\hline Minnesota & $19.5 \mathrm{a}$ & $210 \mathrm{~b}$ \\
British Columbia & $26.9 \mathrm{~b}$ & $122 \mathrm{a}$ \\
\hline
\end{tabular}

${ }^{a}$ Means followed by the same letter do not differ significantly at $p \leq 0.05$.

surprised to see significant differences in overall mean sucker density and height between sites (Table 2). Schier and Zasada (1973), for example, found that at any given sucker number (density) and total nonstructural carbohydrate (TNC) concentration, growth of suckers from excised roots of three Utah clones was greater than that from three Alaskan clones.

\section{Stand and Site Conditions}

Despite the geographic differences between the sites, mean January temperature, stand basal area, and soil conditions are surprisingly similar (Table 1). Mean annual precipitation is $140 \mathrm{~mm}$ less at the $\mathrm{BC}$ site; however, the $5^{\circ} \mathrm{C}$ lower mean July temperature may compensate for the lower precipitation, resulting in sim- 


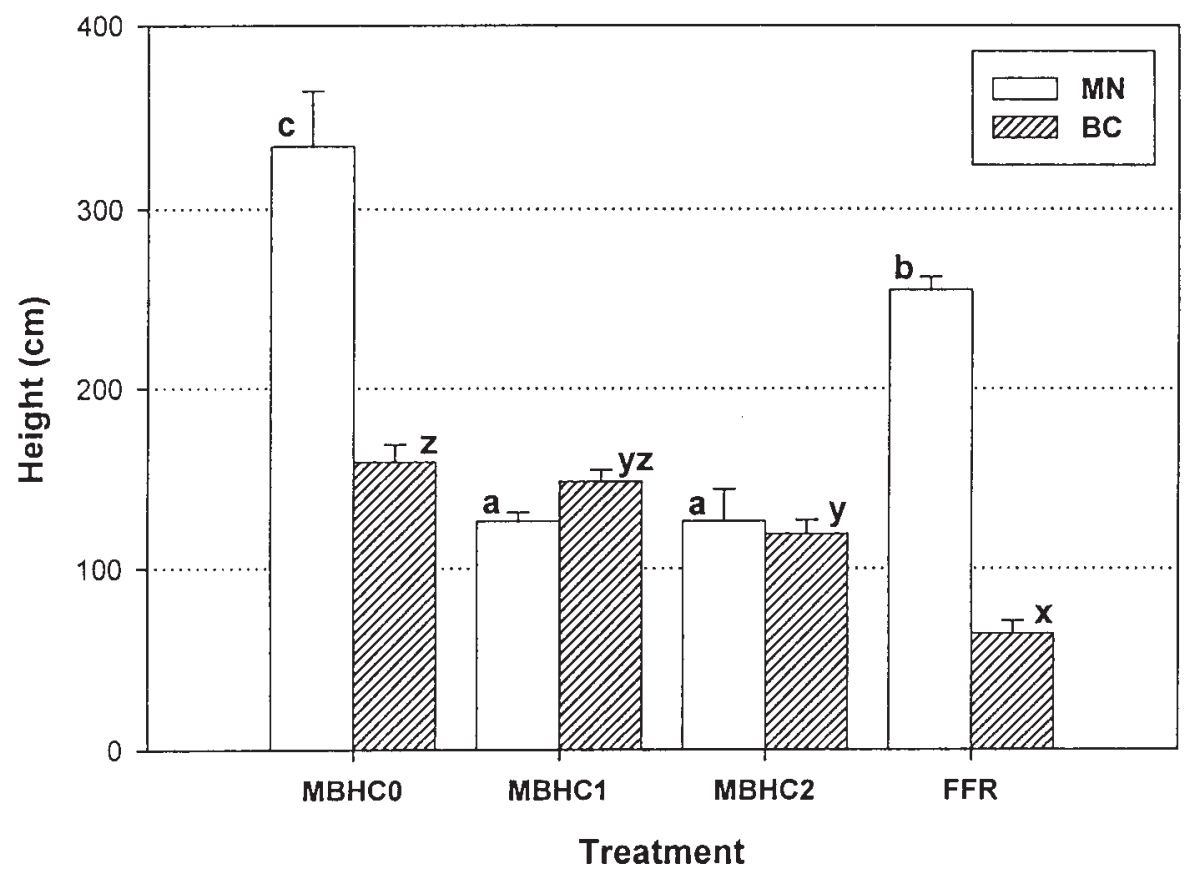

Fig. 2. Mean fifth-year aspen sucker height by treatment; within sites, means followed by the same letter do not differ significantly at $p \leq 0.05$. Treatment codes as in Fig. 1.

ilar growing season evapotranspiration and water balances on the two sites. The somewhat greater basal area and site index on the MN site can be attributed, at least partially, to the thicker silt loam cap. The slightly higher basal area on the MN plots presumably supports a higher leaf area index and provides greater litter production. However, the warmer growing season temperature and greater precipitation favour more rapid decomposition resulting in the lower forest floor thickness and dry weight.

\section{Treatment Effects}

On non-compacted plots, fifth-year sucker density was similar on the two sites (Fig. 1). The compaction treatments drastically reduced sucker density on the MN plots, primarily due to treatment after they had emerged. On this site, effects of compaction on reducing sucker density were dramatic, and not unlike many conventional logging operations in the northern Great Lakes region (Bates et al. 1990, 1993). These results indicate that managers should plan harvesting activities to minimize the area covered by machine traffic (Stone 2002), and avoid traffic in the spring after suckers have begun to emerge. The compaction treatments initially tended to increase first-year sucker density in the BC study, but by the fourth-year the differences by level of compaction were no longer apparent (Kabzems 2000a). Presumably, these initial increases were due to minor root injury during compaction. Disturbance of aspen root systems and increased soil temperatures are known to stimulate sucker production (Schier et al. 1985, Peterson and Peterson 1992). On fine textured (clay) soils, however, the more severe effects of rutting can be highly detrimental to both aspen sucker density and early height growth (Stone and Elioff 2000).

The differences in sucker density may be due to inherent differences in suckering capacity of the clones on the two sites as suggested by initial results from BC and another site in northern MN. The FFR treatment resulted in a first-year sucker density of $>260000 \mathrm{ha}^{-1}$ on a loamy sand site in MN (Alban et al.
1994), and about $220000 \mathrm{ha}^{-1}$ in BC (Kabzems 1996), most likely due to increased soil temperatures and removal of competing vegetation (Kabzems 2000b). By the fourth year, sucker density had declined to about $55000 \mathrm{ha}^{-1}$ in BC (Kabzems 2000a), and by the fifth year, to about $40000 \mathrm{ha}^{-1}$ in MN (Stone and Elioff 1998).

In both $\mathrm{MN}$ and $\mathrm{BC}$, the greatest height growth occurred in the non-compacted treatment (Fig. 2). As with sucker density, the late spring treatment on the MN site also greatly reduced sucker height. Compared to the non-compacted plots, the lower height growth with the FFR treatment most likely is due to the two-fold greater sucker density on those plots. In BC, soil compaction generally decreased sucker height; however, only the differences between the non-compacted and heavily compacted treatments were statistically significant (Fig. 2).The lower early height growth in the FFR treatment likely is due to a combination of water relations and carbohydrate reserves in the parent root systems. First, removal of the forest floor would have reduced the amount of available soil water over the growing season, creating less favorable growing conditions. The intact forest floor would have provided both a reservoir of soil water and a mulch that reduced evaporative losses (Powers 1999). Secondly, the exposure of aspen roots after forest floor removal stimulated the production of multiple suckers from each bud. Thus, the available carbohydrates were distributed over a larger number of stems, limiting the height growth of individual suckers and may have decreased dry weight per sucker (Schier and Zasada 1973). Stone et al. (2001) provided additional evidence for an inverse relation between sucker density and early growth; they found that retaining 18 to 37 mature aspen ha ${ }^{-1}$ decreased sucker density approximately $40 \%$ and increased firstyear diameter and height growth by about $30 \%$.

At the BC installation this depression of sucker height in the FFR treatment has continued into the seventh growing season (unpublished data on file). In the first year, mean height of aspen 


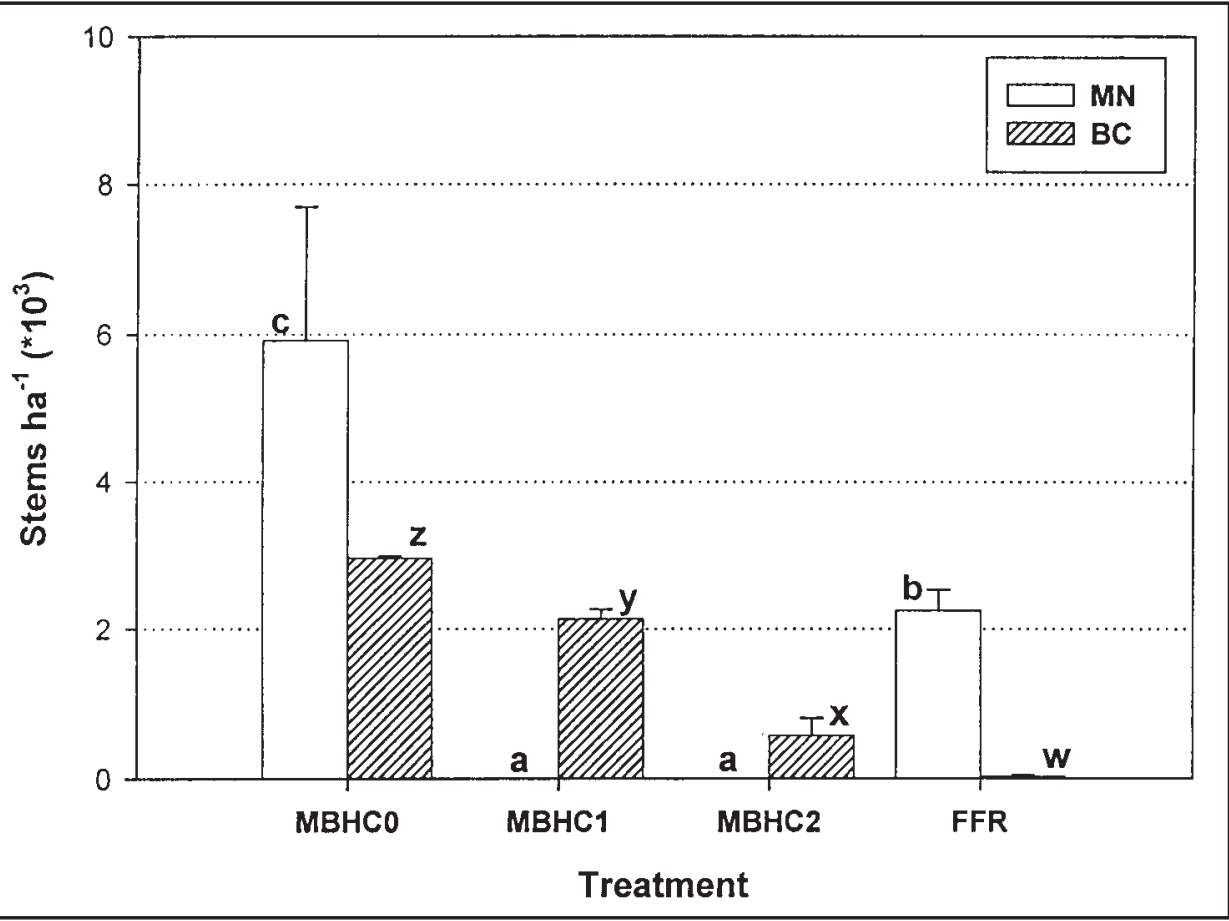

Fig. 3. Mean density of five-yearold aspen suckers $\geq 25 \mathrm{~mm}$ dbh Treatment codes as in Fig. 1.

on the FFR plots was $82 \mathrm{~cm}$ vs. $129 \mathrm{~cm}$ in the non-compacted treatment. After the seventh growing season, suckers in the FFR treatment were $139 \mathrm{~cm}$ in height, having increased only $57 \mathrm{~cm}$ from the first year. Those on the non-compacted plots grew $186 \mathrm{~cm}$ over the same time period, reaching $315 \mathrm{~cm}$ on average.

Stone and Elioff (1998) suggested that the density of fiveyear-old aspen suckers that have reached a breast height diameter (dbh) of $25 \mathrm{~mm}$ may be a useful index of stand development and future productivity. That number may reflect differences in soil conditions due to experimental treatments or those resulting from conventional harvesting operations. On a loamy sand site in MN, non-compacted plots had 5000 ha $^{-1}$ in this size class and less than $1000 \mathrm{ha}^{-1}$ in compacted, FFR, or compacted plus FFR treatments (Stone and Elioff 1998). This compares with the $5900 \mathrm{ha}^{-1}$ on non-compacted plots on the MN silt loam site, and where no suckers in either compaction treatment had attained this size (Fig. 3). In BC, the density of suckers in this size class declined progressively with severity of compaction. On both sites the lower numbers in the FFR treatment most likely are due to the greater sucker density (Fig. 1) combined with less favourable growing conditions.

\section{Conclusions}

Opportunities to compare data from widely separate geographic regions using a similar study design frequently do not exist. Because of this we can make explicit comparisons between early aspen sucker development and responses to experimental soil compaction and organic matter removal treatments. Despite potentially large genetic variation and the geographic differences, treatment responses and aspen development were similar on sites in northern $\mathrm{MN}$ and northeastern $\mathrm{BC}$. The compaction treatments decreased sucker height on both sites. In $\mathrm{MN}$ the decreased sucker density on compacted plots can be partially attributed to the late treatment application. Man- agers should plan harvesting activities to minimize the area covered by machine traffic and avoid traffic after suckers have begun to emerge. To date, the compaction treatments applied in $\mathrm{BC}$ have not significantly affected total numbers of aspen suckers. Compared to non-compacted plots, the FFR treatment significantly increased sucker density and decreased their height on both sites. Likewise, soil compaction decreased the number of suckers that had reached a dbh of $25 \mathrm{~mm}$ after five growing seasons and will likely delay future stand development and reduce site productivity.

\section{Acknowledgements}

We thank David H. Alban (retired), North Central Research Station for installing, and John D. Elioff for maintaining the LTSP studies in the Lake States. Dave Alban, Dan Gilmore, University of Minnesota; Doug Maynard, Canadian Forest Service; Bob Powers, Pacific Southwest Research Station; and John Zasada, North Central Research Station, provided helpful comments and suggestions on an earlier version of the manuscript.

\section{References}

Agren, G.I. (ed.) 1986. Predicting consequences of intensive forest harvesting on long-term productivity. Proceedings, IEA/BE Project CPC-10 workshop, 24-31 May1986. Jodraas, Sweden. 205 p.

Alban, D.H., G.E. Host, J.D. Elioff and D. Shadis. 1994. Soil and vegetation response to soil compaction and forest floor removal after aspen harvesting. USDA For. Serv., North Cent. For. Exp. Stn., Res. Pap. NC-315. 8 p.

Analytical Software. 2000. Statistix 7 for Windows. User's Manual. Tallahassee, FL. 359 p.

Bates, P.C., C.R. Blinn and A.A. Alm. 1990. A survey of the harvesting histories of some poorly regenerated aspen stands in northern Minnesota. In R.D. Adams (ed.). Aspen Symposium '89. pp. 221-230. USDA For. Serv., North Cent. For. Exp. Stn., Gen Tech. Rep. NC-140. 348 p. 
Bates, P.C., C.R. Blinn and A.A. Alm. 1993. Harvesting impacts on quaking aspen regeneration in northern Minnesota. Can. J. For. Res. 23: 2403-2412.

Greacen, E.L. and R. Sands. 1980. Compaction of forest soils: a review. Aust. J. Soil Res. 18: 163-189.

Grier, C.C., K.M. Lee, N.M. Nadkarni, G.O Klock and P.J. Edgerton. 1989. Productivity of forests of the United States and its relation to soil and site factors and management practices: a review. USDA For. Serv., Pacific Northwest Res. Stn., Gen. Tech. Rep. PNW$222.51 \mathrm{p}$.

Harper, K.T., J.D. Shane and J.R. Jones. 1985. Taxonomy. In N.V. DeByle and R.P. Winokur (eds.). Aspen: Ecology and Management in the Western United States. pp. 7-8. USDA For. Serv., Rocky Mountain For. Range Exp. Stn., Gen. Tech. Rep. RM-119. 283 p.

Jones, J.R. and N.V. DeByle. 1985. Genetics and variation. In: DeByle, N.V. and R.P. Winokur (eds.). Aspen: Ecology and Management in the Western United States. pp. 35-39. USDA For. Serv., Rocky Mountain For. Range Exp. Stn., Gen. Tech. Rep. RM-119. 283 p.

Kabzems, R. 1996. Boreal long-term soil productivity study. For. Res. Note \#PG-06. British Columbia Ministry of Forests, Prince George For. Reg. 4 p.

Kabzems, R. 2000a. Fourth year responses of aspen and white spruce: the BWBS long-term soil productivity study. For. Res. Note \#LTSPS-02. British Columbia Ministry of Forests, Prince George For. Reg. 4 p.

Kabzems, R. 2000b. Fourth year plant community responses: the BWBS long-term soil productivity study. For. Res. Note \#LTSPS-03. British Columbia Ministry of Forests, Prince George For. Reg. 4 p. Little, E.L., Jr. 1971. Atlas of United States Trees: Vol. 1. Conifers and Important Hardwoods. USDA For. Serv., Misc. Pub. 1146. p. 9 + 202 maps. Washington, D.C.

Perala, D.A., R.A. Leary and C.J. Cieszewski. 1995. Stockability, growth, and yield of the circumboreal aspens (Populus tremuloides Michx., P. tremula L.). USDA For. Serv., North Cent. For. Exp. Stn., Res. Pap. NC-321. 24 p.

Perala, D.A., R.A. Leary and C.J. Cieszewski. 1999. Self-thinning and stockability of the circumboreal aspens (Populus tremuloides Michx., P. tremula L.). USDA For. Serv., North Cent. For. Exp. Stn., Res. Pap. NC-335. 16 p.

Peterson, E.B. and N.M Peterson. 1992. Ecology, management, and use of aspen and balsam poplar in the prairie provinces, Canada. Special Report \#1. For. Canada, Northwest Reg., North. For. Cent., Edmonton, AB. 252 p.

Powers, R.F. 1999. On the sustainable productivity of planted forests. New Forests 17: 263-306.

Powers, R.F., D.H. Alban, R.E. Miller, A.E. Tiarks, C.G. Wells, P.E. Avers, R.G. Cline, R.O. Fitzgerald and N.S. Loftus, Jr. 1990. Sustaining site productivity in North American forests: problems and prospects. In S.P. Gessel, D.S. Lacate, G.F. Weetman and R.F. Powers (eds.). Sustained Productivity of Forest Soils. Proc. $7^{\text {th }}$ North Amer. For. Soils Conf. pp. 49-79. Univ. British Columbia, Faculty of Forestry Publication. Vancouver, B.C. 525 p.
Schier, G.A. and J.C. Zasada. 1973. Role of carbohydrate reserves in the development of root suckers in Populus tremuloides. Can. J. For. Res. 3: 243-250.

Schier, G.A., W.D. Sheppard and J.R. Jones. 1985. Regeneration. In N.V. DeByle and R.P. Winokur. (eds.). Aspen: Ecology and Management in the Western United States. pp. 197-208. USDA For. Serv., Rocky Mountain For. Range Exp. Stn., Gen. Tech. Rep. RM119. $283 \mathrm{p}$.

Standish, J.T., P.R. Commandeur and R.B. Smith. 1988. Impacts of forest harvesting on physical properties of soils with reference to increased biomass recovery: a review. Can. For. Serv., Pacific For. Cent., Inform. Rep. BC-X-301. 24 p.

Stone, D.M. 2001. Sustaining aspen productivity in the Lake States. In W.D. Shepperd, D. Binkley, D.L. Bartos, T.J. Stohlgren and L.G. Eskew (comps.). Sustaining Aspen in Western Landscapes: Symposium Proceedings. pp. 47-59. USDA For. Serv., Rocky Mountain Res. Stn., Proc. RMRS-P-18. 460 p.

Stone, D.M. 2002. Logging Options to Minimize Soil Disturbance in the Northern Lake States. North. J. Appl. For. 19(3): 115-121.

Stone, D.M. and J.D. Elioff. 1998. Soil properties and aspen development five years after compaction and forest floor removal. Can. J. Soil Sci. 78: 51-58.

Stone, D.M. and J.D. Elioff. 2000. Soil disturbance and aspen regeneration on clay soils: three case histories. For. Chron. 76: 747-752.

Stone, D.M., J.A. Gates and J.D. Elioff. 1999.Are we maintaining aspen productivity on sand soils? In B. ZumBahlen and A.R. Ek. (comps.). Improving Forest Productivity For Timber - A Key to Sustainability. pp. 177-184. Dept. For. Resour. Univ. Minnesota, St. Paul, MN. 360 p.

Stone, D. M., J.D. Elioff, D.V. Potter, D.B. Peterson and R. Wagner. 2001. Restoration of Aspen-Dominated Ecosystems in the Lake States. In W.D. Shepperd, D. Binkley, D.L. Bartos, T.J. Stohlgren and L.G. Eskew (comps.). Sustaining Aspen in Western Landscapes: Symposium Proceedings. pp. 137-143. USDA For. Serv., Rocky Mountain Res. Stn., Proc. RMRS-P-18. 460 p.

Tiarks, A.E., R.F. Powers, D.H. Alban, G.A. Ruark, and D.S. PageDumroese. 1993. USFS Long-term soil productivity national research project: a USFS cooperative research program. In J.M. Kimble (ed.). 1993. Proc. $8^{\text {th }}$ International Soil Management Workshop: Utilization of Soil Survey Information for Sustainable Land Use. pp. 236-241. USDA Soil Conservation Service, National Soil Survey Center, Lincoln, NE. 